\title{
The Role of Probiotics in Suppressing Campylobacter jejuni Infection in Broilers: Performance Parameters
}

\author{
T E M Nahak ${ }^{1}$, V C Prakasita ${ }^{2}$, L N Imanjati ${ }^{1}$, S L Adrenalin ${ }^{3}$, C R Tabbu ${ }^{4}$ and A E \\ T H Wahyuni ${ }^{5, *}$ \\ ${ }^{1}$ Veterinary Science Study Program, Faculty of Veterinary Medicine, Universitas Gadjah Mada, Jl. Fauna No. 2 , \\ Sleman, Yogyakarta, 55281, Indonesia \\ ${ }^{2}$ Departement of Biology, Faculty of Biotechnology, Duta Wacana Christian Univercity, Jl. Dr. Wahidin \\ Sudirohusodo No.5-25, Kotabaru, Gondokusumanan, Yogyakarta, 55224, Indonesia \\ ${ }^{3}$ Faculty of Veterinary Medicine, Brawijaya University, Jl. Puncak Dieng, Malang, Jawa Timur, 65151, Indonesia \\ ${ }^{4}$ Department of Pathology, Faculty of Veterinary Medicine, Universitas Gadjah Mada, Jl. Fauna No. 2, Sleman, \\ Yogyakarta, 55281, Indonesia \\ ${ }^{5}$ Department of Microbiology, Faculty of Veterinary Medicine, Universitas Gadjah Mada, Jl. Fauna No. 2, Sleman, \\ Yogyakarta, 55281, Indonesia \\ ${ }^{*}$ Corresponding author. Email: wahyuni_aeth@mail.ugm.ac.id
}

\begin{abstract}
The use of probiotics as feed additives in farms has been widely known both at a small and large scale. As a substitute for the Antibiotic Growth Promoter (AGP) that has been banned for animal feed, probiotics are used in broilers feeds to improve their performance. Campylobacter jejuni is a type of pathogenic bacteria that often infect birds, especially broilers, and reduce broiler's performance. This study aims to reveal the role of probiotics in the performance of broilers infected by Campylobacter jejuni. A total of 21 broiler Day Old Chicks (DOC) were divided into 3 groups of 7 with different diets: Group K as the control group were given basal diet, Group BA were given a mixture of basal diet and AGP, and Group BP were given a mixture of basal diet and probiotics. This treatment was implemented for 5 straight weeks. In week 3, a Campylobacter jejuni challenge test was conducted using body weight (BW), body weight gain (BWG), and carcass percentage (CP) as the performance parameters. In terms of BW, from week 1 to week 3 no significant differences were found among the groups. In week 4, however, Group BP had a significantly higher BW that Group K, but insignificantly higher than Group BA. In terms of BWG, from week 1 to week 3 there was also no significant differences among the groups. However, in week 4, BWG in Group BP was found to be significantly higher than that of the other two groups. Finally, in terms of CP, Group BP was found to have higher CP than the other two groups, although the difference is not significant. These results show that probiotics can improve broilers' performance by suppressing Campylobacter jejuni infection.
\end{abstract}

Keywords: Probiotics, AGP, Campylobacter jejuni, Broiler, Performance.

\section{INTRODUCTION}

Feed is an important factor that supports livestock productivity, especially broilers. The use of quality feed and good feed additives can support the successful production of broilers. A type of the feed additives that have long been used is Antibiotic Growth Promoter (AGP). Nowadays, however, the use of AGP as a growth promoter has been banned in animal feeds, considering its negative impacts such as antimicrobial resistance [1]. As an alternative, probiotics have since been more popular. Probiotics are nonpathogenic living organisms present in some foods, which have positive effects on the health of the hosts if they enter the body in a sufficient amount [2]. Probiotics have been widely 
used by farmers both at a small and large scale as a safe feed supplement without any adverse effects.

Campylobacter sp. is a type of gram-negative and microaerophilic bacteria that zoonotically spread throughout the world. In human, Campylobacter sp. infection is called campylobacteriosis, which is

\section{MATERIAL AND METHODS}

\subsection{Research Ethical Clearance Approval}

This research was approved by the Research Ethics

Commission of the Faculty of Veterinary Medicine,

Table 1. The composition of commercial feed

\begin{tabular}{lccc}
\hline \multirow{2}{*}{ Component } & \multicolumn{3}{c}{ Feeding phase } \\
\cline { 2 - 4 } & Prestarter & Starter & Finisher \\
\hline Water content (\%) Max & 13 & 13 & 13 \\
Protein (\%) & $23.0-25.0$ & $22.0-24.0$ & $20.0-23.0$ \\
Fat (\%) Min & 4 & 4 & 5 \\
Ash (\%) Max & 7 & 7 & 8 \\
Crude fiber (\%) Max & 5 & 5 & 5 \\
Ca (\%) Min & 0.9 & 0.9 & 0.9 \\
P (\%) Min & 0.6 & 0.6 & 0.6 \\
Lysin (\%) Min & 1.32 & 1.19 & 1.05 \\
Methionine (\%) Min & 0.50 & 0.48 & 0.43 \\
Methionine + cysteine (\%) Min & 0.98 & 0.89 & 0.82 \\
Tryptophan (\%) Min & 0.20 & 0.19 & 0.19 \\
Treonine (\%) Min & 0.86 & 0.78 & 0.71 \\
\hline
\end{tabular}

characterized by certain symptoms such as waterymucous diarrhea, often accompanied by blood in feces,

nausea, vomiting, abdominal pain, and fever lasting for seven days or longer [3]. Campylobacteriosis in human is mainly caused by $C$. jejuni, constituting about $90 \%$ of cases, while the remainder is caused by $C$. coli [4]. The main source of campylobacteriosis transmission is undercooked chickens or ready-to-eat food that has come in contact with raw chickens. In chickens, Campylobacter sp. infection can cause jejunal distention, hemorrhagic enteritis, and focal necrosis in the liver [5]. This can cause a decrease in the absorption of nutrients in the food consumed. In other words, it leads to a poor performance.

The mechanism of action of probiotics in inhibiting enteropathogenic bacteria in the adhesion to the surface of intestinal epithelial cells is by producing antimicrobial compounds, reducing intestinal $\mathrm{pH}$, and increasing the barrier function of the intestine [6]. The use of probiotics is a solution to enteropathogenic bacterial infections such as $C$. jejuni. This is confirmed by several previous studies that proved the ability of probiotics to inhibit and reduce infections from enteropathogenic bacteria such as Salmonella enteritidis and Clostridium perfringens [7, 8]. Therefore, it is necessary to conduct a research on the role of probiotics in inhibiting $C$. jejuni infection in broilers in terms of performance.

\section{UGM (0038/EC-FKH /Int/2018)}

\subsection{Experimental Design}

A total of 21 day-old broilers (Cobb) were divided randomly into 3 groups, each of which consisted of 7 chickens with a different diet: the first group (Group K) was the control group that was given basal feed; the second group (Group BA) was given a mixture of basal feed and AGP (enramycin) at a dose of $250 \mathrm{gr} / \mathrm{ton}$; and the third group (Group BP) was given a mixture of basal feed and probiotics at a dose of $1 \mathrm{~kg} / \mathrm{ton}$. The probiotics used were obtained from commercial products containing Bacillus amiloliquefaciens at a concentration of $1 \times 10^{9} \mathrm{CFU} / \mathrm{g}$. Finally, the basal feed used was AGPfree, the composition of which can be seen in Table 1 .

Certain treatments were implemented for 5 weeks. First, vaccination was given to all chicken on day 1 with ND+IB live vaccine (intraocular), on day 14 with IBD live (oral), and on day 18 with a booster vaccine namely ND killed vaccine (intramuscular). Second, the room temperature was maintained at $35^{\circ} \mathrm{C}$ for the first 3 days, and then gradually reduced by an increment of $3^{\circ} \mathrm{C}$ per week until it reached $24^{\circ} \mathrm{C}$. Last, all chickens had ad libitum access to feed and water throughout the experiment.

\subsection{Bacteria Reactivation}

C. jejuni isolates were obtained from the Center for Veterinary Research (BALITVET) with an isolate code 
Table 2. Body weight (BW) from group K, BA and BP

\begin{tabular}{|c|c|c|c|c|c|}
\hline \multirow[t]{2}{*}{ Group } & \multicolumn{5}{|c|}{$\mathrm{BW}(\mathrm{g})$} \\
\hline & Week 1 & Week 2 & Week 3 & $\begin{array}{l}\text { Week } 4 \\
(7 \mathrm{dpc})\end{array}$ & $\begin{array}{l}\text { Week } 5 \\
(14 \mathrm{dpc})\end{array}$ \\
\hline $\mathrm{K}$ & $139.83 \pm 7.29^{\mathrm{a}}$ & $439.83 \pm 21.25^{\mathrm{a}}$ & $889.33 \pm 54.63^{\mathrm{a}}$ & $1065.83 \pm 62.15^{a}$ & $1651.33 \pm 123.65^{a}$ \\
\hline BA & $164.00 \pm 11.24^{\mathrm{a}}$ & $503.33 \pm 23.75^{\mathrm{a}}$ & $942.50 \pm 23.64^{\mathrm{a}}$ & $1228.16 \pm 26.83^{\mathrm{ab}}$ & $1825.00 \pm 42.53^{\mathrm{a}}$ \\
\hline $\mathrm{BP}$ & $168.33 \pm 5.81^{\mathrm{a}}$ & $508.00 \pm 24.50^{\mathrm{a}}$ & $1001.50 \pm 40.83^{\mathrm{a}}$ & $1339.80 \pm 55.61^{b}$ & $1916.00 \pm 57.39^{\mathrm{a}}$ \\
\hline $\begin{array}{l}\text { Significan } \\
\text { Level } \\
(\mathrm{P}<0.05)\end{array}$ & ns & ns & ns & $*$ & ns \\
\hline
\end{tabular}

Table 3. Body weight gain (BWG) from group K, BA and BP

\begin{tabular}{|c|c|c|c|c|c|}
\hline \multirow[t]{2}{*}{ Group } & \multicolumn{5}{|c|}{ BWG (g) } \\
\hline & Week 1 & Week 2 & Week 3 & $\begin{array}{l}\text { Week } 4 \\
(7 \mathrm{dpc})\end{array}$ & $\begin{array}{l}\text { Week } 5 \\
(14 \mathrm{dpc})\end{array}$ \\
\hline $\mathrm{K}$ & $88.83 \pm 7.34^{\mathrm{a}}$ & $300.00 \pm 17.03^{\mathrm{a}}$ & $449.16 \pm 33.88^{a}$ & $176.50 \pm 16.56^{\mathrm{a}}$ & $618.66 \pm 33.96^{a}$ \\
\hline BA & $110.33 \pm 10.66^{\mathrm{a}}$ & $339.66 \pm 12.81^{\mathrm{a}}$ & $493.50 \pm 7.42^{\mathrm{a}}$ & $226.66 \pm 32.95^{\mathrm{a}}$ & $615.80 \pm 42.37^{a}$ \\
\hline BP & $107.16 \pm 6.67^{\mathrm{a}}$ & $339.33 \pm 19.23^{a}$ & $439.50 \pm 18.71^{\mathrm{a}}$ & $365.20 \pm 41.25^{\mathrm{b}}$ & $577.00 \pm 31.36^{\mathrm{a}}$ \\
\hline $\begin{array}{l}\text { Significant } \\
\text { Level } \\
(\mathrm{P}<0.05)\end{array}$ & ns & ns & ns & $*$ & ns \\
\hline
\end{tabular}

\subsection{Performance Parameters}

2910. The isolate was then reactivated by infecting $21-$ days-old broilers orally at a concentration of $1 \times 10^{9}$ $\mathrm{CFU} / \mathrm{mL}$ [9]. These broilers were observed for any clinical signs for 7-14 days post challenge (dpc). Those showing clinical signs were discharged and then the bacteria were isolated from the caecal contents on blood agar plates and incubated at $42^{\circ} \mathrm{C}$ for 24 hours. Bacteria with round gray colonies and non-hemolytic were taken for gram staining. Spiral, gram-negative bacteria were identified through biochemical testing. The isolated bacteria were then stored for challenging test.

\subsection{Challenge Test}

Reactivated $C$. jejuni isolates were then cultured in Brain Heart Infusion (BHI) media and incubated at $42^{\circ} \mathrm{C}$ for 24 hours. Suspension was made according to the challenge test using Mc Farland standard at a concentration of $1 \times 10^{9} \mathrm{CFU} / \mathrm{mL}$ [9]. C. jejuni was challenged orally in week 3 .
Body weight gain (BWG) and body weight (BW) were calculated every week from week 1 to week 5 . Broilers were weighed in the morning before any food and drinking water were given. Five broilers were taken randomly from each group at week 5 and then slaughtered to calculate the carcass percentage (CP), that is, the percentage of the broiler's carcass weight compared to its live weight.

\subsection{Data Analysis}

All data obtained were analyzed using the One-Way ANOVA test on a statistical program (SPSS 24). If any significant differences were found, a Tukey post hoc test was performed. The data were presented in the form of mean \pm standard of error (Mean $\pm \mathrm{SE}$ ). The significant level used was $\mathrm{P}<0.05$.

\section{RESULT AND DISCUSSION}

From week 1 to week 2, no significant differences $(\mathrm{P}>0.05)$ were found between groups. Similarly, in week 5 (14 dpc), no significant differences $(\mathrm{P}>0.05)$ 
was found between groups. In week 4 (7 dpc), however, Group BP was found to have a significantly higher BW $(\mathrm{P}<0.05)$ that Group K. The BW of Group BP in the same week was also higher than that of Group BA, but not significantly $(\mathrm{P}>0.05)$ (Table 2$)$. There was also no significant difference $(\mathrm{P}>0.05)$ found in $\mathrm{BWG}$ among the groups from week 1 to week 4 . Similar results were also obtained in week $5(14 \mathrm{dpc})$. In week 4 (7 dpc), however, the BWG of Group BP was found to be significantly higher $(\mathrm{P}<0.05)$ than that of both Group $\mathrm{K}$ and Group BA (Table 3). No significant differences

Table 4. Carcas percentage from groups K, BA and BP

\begin{tabular}{lc}
\hline Group & Carcass Percentage $(\%)$ \\
\hline K & $60.68 \pm 8.28^{\mathrm{a}}$ \\
BA & $71.87 \pm 2.75^{\mathrm{a}}$ \\
BP & $74.29 \pm 1.05^{\mathrm{a}}$
\end{tabular}

Significant

Level

ns

$(\mathrm{P}<0.05)$

${ }^{a}$ The same superscripts in each row show no significant differences $(\mathrm{P}>0.05)$ between groups

${ }^{\mathrm{ns}}$ non significant differences

( $\mathrm{P}>0.05)$ was found among the groups. In general, Group BP had a higher percentage of carcass than Group K and Group BA (Table 4).

The negative effects of using AGP as feed additives in animal feed has caused a shift to non-antibiotic feed supplements as alternative substitute for AGP in various countries. Among the popular alternatives are probiotics, which have been developed for a long time and widely used in farms. Some types of microorganisms that are often used as probiotics are Lactobacillus bulgaricus, $L$. acidophillus, L. casei, L. helveticus, L. salvarius, $L$. plantarum, L. faecalis, Streptococcus thermophilus, Enterococcus faecium, Enterobactris faecalis, Bifidobacteria species, Saccharomyces cerevisiae, and Toulopsis sphaerica. Among these types of bacteria, Lactobacilli and Streptococci are the most-widely used [10].

Used as feed additives, probiotics have been found to inhibit the colonization of several enteropathogenic bacteria. Campylobacter jejuni, for instance, is an enteropathogenic bacteria that causes a decrease in broilers' performance. Several previous studies in vivo reveal that the use of probiotics (E. faecium, Pediococcus acidilactici, L. salivarius, and $L$. reuteri) can reduce $C$. jejuni colonization in broilers [11]. Willis and Reid [12] also reveal that broilers fed with probiotics (L. acidophilus, L. casei, B. thermophiles, and E. faecium $\left(10^{8} \mathrm{CFU} / \mathrm{g}\right)$ can reduce the population of $C$. jejuni compared to controls.

Adhesion, internalization, and translocation are the main mechanisms of Campylobacter infection [13,14]. Flagella $C$. jejuni plays an important role in successful colonization, motility, and survival [15]. Probiotics' mechanism of action in inhibiting $C$. jejuni colonization includes them influencing the motility and viability of $C$. jejuni by decreasing the luminal $\mathrm{pH}$ of the intestine and producing bacteriocin $[16,17,18]$. Environmental temperature, $\mathrm{pH}$, and the concentration of certain inorganic compounds have been found to affect the activity of flagella (flaA and flab) so that it can affect $C$. jejuni motility [19]. Probiotics can inhibit C. jejuni translocation by increasing tight junctions of the intestinal epithelium [20] and probiotics can modulate the immune system to act against Campylobacter [21].

The mechanism of action of probiotics in inhibiting colonization and motility of $C$. jejuni can be seen from the results of this study. In terms of performance, the group given probiotics had a better performance than the other groups when they are challenged with $C$. jejuni. The performance parameters observed in this study are body weight, body weight gain, and carcass percentage. In addition to their ability to inhibit colonization and motility of $C$. jejuni, probiotics are also capable of improving broilers' performance by increasing digestibility and absorption of nutrients [22], and increasing the activity of digestive enzymes [23].

This mechanism of action shows that probiotics are feed additives that are able to inhibit $C$. jejuni colonization and motility and improve the performance of broilers. Probiotics' mechanism of action is also expected to inhibit and reduce the infection of enteropathogenic bacteria, which negatively affects the performance of broilers. Further research using enteropathogenic bacteria are encouraged to understand, with certainty, the role of probiotics to fight these pathogenic bacteria.

\section{CONCLUSION}

Probiotic administration can reduce $C$. jejuni infection so that it can improve the performance (by increasing the $\mathrm{BW}, \mathrm{BWG}$, and $\mathrm{CP}$ ) of broilers. Probiotics can be a replacement for AGP as a feed supplement in broilers to reduce the incidence of antimicrobial resistance.

\section{REFERENCES}

[1] Milanov DS, Ljubojević DB, Čabarkapa IS and Aleksić NZ 2016 Impact of antibiotics used as growth promoters on bacterial resistance Food and Feed Research 43 83-92

[2] Mousavi SMAA, Hosseini HM and Mirhosseini SA 2018 A Rview of Dietary Probiotics in Poultry J. Appl. Biotechnol. Rep. 5 48-54

[3] Epps SV, Harvey RB, Hume ME, Phillips TD, Anderson RC and Nisbet DJ 2013 Foodborne Campylobacter: infections, metabolism, 
pathogenesis and reservoirs Int. J. Environ. Res. Public Health 10 6292-6304

[4] Gibreel A and Taylor DE 2006 Macrolide resistance in Campylobacter jejuni and Campylobacter coli J. Antimicrob. Chemother. 58 243-255

[5] Workman SN, Mathison GE and Lavoie MC 2005 Pet dogs and chicken meat as reservoirs of Campylobacter spp. in Barbados J. Clin. Microbiol. 43 2642-2650

[6] Ng SC, Hart AL, Kamm MA, Stagg AJ and Knight SC 2009 Mechanisms of action of probiotics: recent advances Inflamm. Bowel Dis. 15 300-310

[7] Wolfenden AD, Vicente JL, Higgins JP, Andreatti Filho RL, Higgins SE, Hargis BM and Tellez G 2007 Effect of Organic Acids and Probiotics on Salmonella enteritidis Infection in Broiler Chickens Int. J. Poult. Sci. 6 403405

[8] Li Z, Wang W, Liu D and Guo Y 2018 Effects of Lactobacillus acidophilus on the growth performance and intestinal health of broilers challenged with Clostridium perfringens $J$. Anim. Sci. Biotech. 925.

[9] Naseri KG, Rahimi S and Khaki P 2012 Comparison of the Effects of Probiotic, Organic Acid and Medicinal Plant on Campylobacter jejuni Challenged Broiler Chickens J. Agr. Sci. Tech. 14 1485-1496

[10] Jadhav K, Sharma KS, Katoch S, Sharma VK and Mane BG 2015 Probiotics in Broiler Poultry Feeds: A Review Journal of Animal Nutrition and Physiology 1 04-16

[11] Ghareeb K, Awad WA, Mohnl M, Porta R, Biarnés M, Böhm J and Schatzmayr G 2012 Evaluating the efficacy of an avian-specific probiotic to reduce the colonization of Campylobacter jejuni in broiler chickens Poult. Sci. 91 1825-1832

[12] Willis WL and Reid L 2008 Investigating the effects of dietary probiotic feeding regimens on broiler chicken production and Campylobacter jejuni presence Poult. Sci. 87 606-611.

[13] Poly F and Guerry P 2008 Pathogenesis of Campylobacter Curr. Opin. Gastroenterol. 24 27-31

[14] Young KT, Davis LM and Dirita VJ 2007 Campylobacter jejuni: molecular biology and pathogenesis Nat. Rev. Microbiol. 5 665-679

[15] Woodall CA, Jones MA, Barrow PA, Hinds J, Marsden GL, Kelly DJ, Dorrell N, Wren BW and Maskell DJ 2005 Campylobacter jejuni gene expression in the chick cecum: evidence for adaptation to a lowoxygen environment Infect. Immun. 73 5278-5285

[16] Alemka A, Clyne M, Shanahan F, Tompkins T, Corcionivoschi N and Bourke B 2010 Probiotic colonization of the adherent mucus layer of HT29MTXE12 cells attenuates Campylobacter jejuni virulence properties Infect. Immun. 78 2812-2822

[17] Neal-McKinney JM, Lu X, Duong T, Larson CL, Call DR, Shah DH and Konkel MH 2012 Production of Organic Acids by Probiotic Lactobacilli Can Be Used to Reduce Pathogen Load in Poultry PLoS ONE 743928.

[18] Messaoudi S, Kergourlay G, Dalgalarrondo M, Choiset Y, Ferchichi M, Prévost H, Pilet MF, Chobert JM, Manai M and Dousset X 2012 Purification and characterization of a new bacteriocin active against Campylobacter produced by Lactobacillus salivarius SMXD51 Food Microbiol. 32 129-134

[19] Alm RA, Guerry P and Trust TJ 1993 The Campylobacter sigma 54 flaB flagellin promoter is subject to environmental regulation J. Bacteriol. 175 4448-4455

[20] Messaoudi S, Madi A, Prévost H, Feuilloley M, Manai M, Dousset X and Connil N 2012 In vitroevaluation of the probiotic potential of Lactobacillus salivarius SMXD51. Anaerobe 18 584-589

[21] Brisbin JT, Gong J, Orouji S, Esufali J, Mallick AI, Parvizi P, Shewen PE and Sharif S 2011 Oral treatment of chickens with lactobacilli influences elicitation of immune responses Clin. Vaccine Immunol. 18 1447-1455

[22] Rodjan P, Soisuwan K, Thongprajukaew K, Theapparat Y, Khongthong S, Jeenkeawpieam J and Salaeharae T 2017 Effect of organic acids or probiotics alone or in combination on growth performance, nutrient digestibility, enzyme activities, intestinal morphology and gut microflora in broiler chickens J. Anim. Physiol. Anim. Nutr. 102 931-940

[23] Wang Y and Gu Q 2010 Effect of probiotic on growth performance and digestive enzyme activity of Arbor Acres broilers Res. Vet. Sci. 89 163-167 